\title{
www.czasopisma.pan.pl \\ Repair of Structural Steel Surface Groove by Using Flame Welding Method by Spraying Pure Iron Powder
}

\author{
P. Keyhany ${ }^{a}$, S.E. Vahdat ${ }^{\mathrm{b}, *}$ \\ ${ }^{a}$ Department of Engineering, Bandar Abbas Branch, Islamic Azad University, Bandar Abbas, Iran \\ ${ }^{\mathrm{b}}$ Department of Engineering, Ayatollah Amoli Branch, Islamic Azad University, Amol, Iran \\ *Corresponding author. E-mail address: e.vahdat@iauamol.ac.ir
}

Received 02.12.2015; accepted in revised form 21.01.2016

\begin{abstract}
To improve mechanical properties and increasing useful life of metal pieces, different methods of welding are used for repairing surface crack of metal pieces. In this research, performance of flame welding method by spraying pure iron powder evaluated for repairing surface grooves of structural steel. First, four specimens including one control specimen and other three specimens grooved specimens in depth of $1 \mathrm{~mm}$ and in length of $12.5 \mathrm{~mm}$ and groove width in the sizes of $0.5,0.75$ and $1 \mathrm{~mm}$. were prepared then, powder melted using oxyacetylene reducing flame and spraying iron powder in the flame path and attached to the inner surface of the groove and finally, the specimen repaired. Results showed that after repairing surface groove, tensile strength of the repaired specimens were reached to the tensile strength of control specimen with the margin of $2.5 \%$.
\end{abstract}

Keywords: Oxyacetylene, Reducing flame, Tensile strength

\section{Introduction}

Nowadays industrial game, preventive measures for maintenance and repair of the machinery and equipment are of special importance. Failure to identify cracks and action to prevent its growth and spread causes the tragic events. Failure in the metals mostly occur in premature. So, it provides crisis conditions. For example, emergence of failure in the metal pieces of military equipment during attack, defend or retreat will determine a disaster. Another example is that emergence of failure in the metal pieces of drilling equipment when drilling oil or gas well leads to rework and spending high costs. Another example is the emergence of failure in the diesel engine parts of ships during the chase pirates and enemy that leads to failure in doing task and even destruction. In all above cases, a quick and simple repair can prevent the stop of device and provide the ability to pass from crisis. Then, one can repair or replace defective pieces in appropriate conditions.

One of the most commonly used methods for repairing surface cracks of the metal pieces is to use arc welding with manual electrodes. The biggest limitation of this method is to create numerous metallurgical defects in the repair site [1]. Other methods include flame welding by spraying powder [2-4], Welding on the furnace [5] and drilling and screw-working [6]. Fatigue strength and tensile strength are improved with the help of flame welding method by spraying iron powder done in the location of the cross connection in repairing surface cracks of steel cross connections [3-4].

In repairing surface crack of nickel base super alloy with the help of flame welding by spraying powder was shown that repaired 
structure is more fine grain and has more strength than conventional repair methods [7-8].

In welding on the furnace method, the whole piece is heated and so, surface oxidation is occurred and partly leads to change microstructure. In addition, this method is useful for big pieces [5].

Drilling and screwing alone is not known as an effective method, but if it used in combination with other methods will be useful [6].

In this paper, it is tried to repair steel surface grooves with the help of flame welding method by spraying pure iron powder in the flame path. So, the goal is to determine performance of repairing structural steel surface groove by the flame welding by and spraying the pure iron powder in the flame path. In the other words, the purpose of this research was to achieve the tensile strength of control specimen after repairing of grooved specimens.

\section{Materials and Method}

Rough steel sheet purchased from Sepahan Steel Company and chemical composition of the sheet was determined by using Applied Research Laboratories (ARL) machine in Razi Metallurgical Research Center (RMRC) and it listed in Table 1. According to ASTM A370 standard [9], tensile test specimens in thickness of $6 \mathrm{~mm}$ were prepared according to Figure 1 and provided in Razi Research Center. In RMRC, three tensile test specimens were used for determining tensile strength of base metal and elongation of relative length of base metal using tensile machine GOTECH7100L. According to Table 2, average tensile strength of control specimen determined $462 \mathrm{MPa}$ and average elongation of relative length of base metal was determined $33.3 \%$. Therefore, the purpose of this research was to achieve the tensile strength of $462 \mathrm{MPa}$ and relative elongation of $33.3 \%$ after repairing of grooved specimens. Also, metallographic of specimens in the sizes of $8 \times 15 \mathrm{~mm}$ prepared and provided in RMRC.

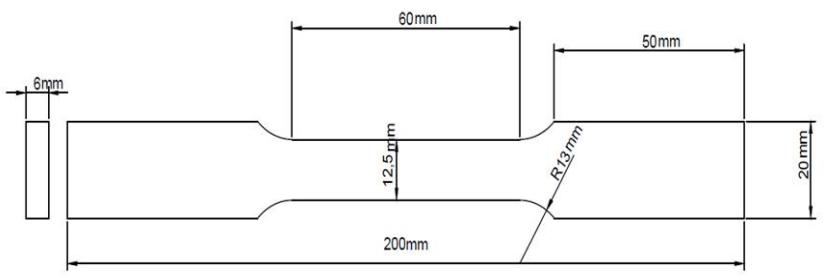

Fig. 1. Sizes and shape of tensile specimen

Table 1.

Chemical composition of steel (control specimen)

\begin{tabular}{cccccccccc}
\hline $\mathbf{C}$ & $\mathbf{S i}$ & $\mathbf{S}$ & $\mathbf{P}$ & $\mathbf{M n}$ & $\mathbf{N i}$ & $\mathbf{C r}$ & $\mathbf{M o}$ & $\mathbf{V}$ & $\mathbf{C u}$ \\
\hline 0.12 & 0.05 & 0.011 & 0.025 & 0.70 & 0.001 & 0.004 & 0.002 & 0.003 & 0.11 \\
\hline $\mathbf{T i}$ & $\mathbf{A s}$ & $\mathbf{S n}$ & $\mathbf{C o}$ & $\mathbf{A l}$ & $\mathbf{P b}$ & $\mathbf{N b}$ & $\mathbf{W}$ & $\mathbf{F e}$ \\
\hline 0.001 & 0.008 & 0.02 & 0.05 & 0.006 & 0.001 & 0.002 & 0.003 & Balance \\
\hline
\end{tabular}

Table 2.

Mechanical properties of steel (control specimen)

\begin{tabular}{ccc}
\hline Specimen No. & $\begin{array}{c}\text { Tensile } \\
\text { strength MPa }\end{array}$ & Elongation in percent \\
\hline 1 & 461 & 33.5 \\
\hline 2 & 456 & 34 \\
\hline 3 & 470 & 32.5 \\
\hline Mean & $\mathbf{4 6 2}$ & $\mathbf{3 3 . 3}$ \\
\hline
\end{tabular}

To repair, $300 \mathrm{~g}$ of the pure iron powder purchased from Azna Ferroalloy Company. Scanning electron microscopy (SEM) image with the energy spectrum (EDS), Figure 2, and the average grain size of iron powder is 33 microns.
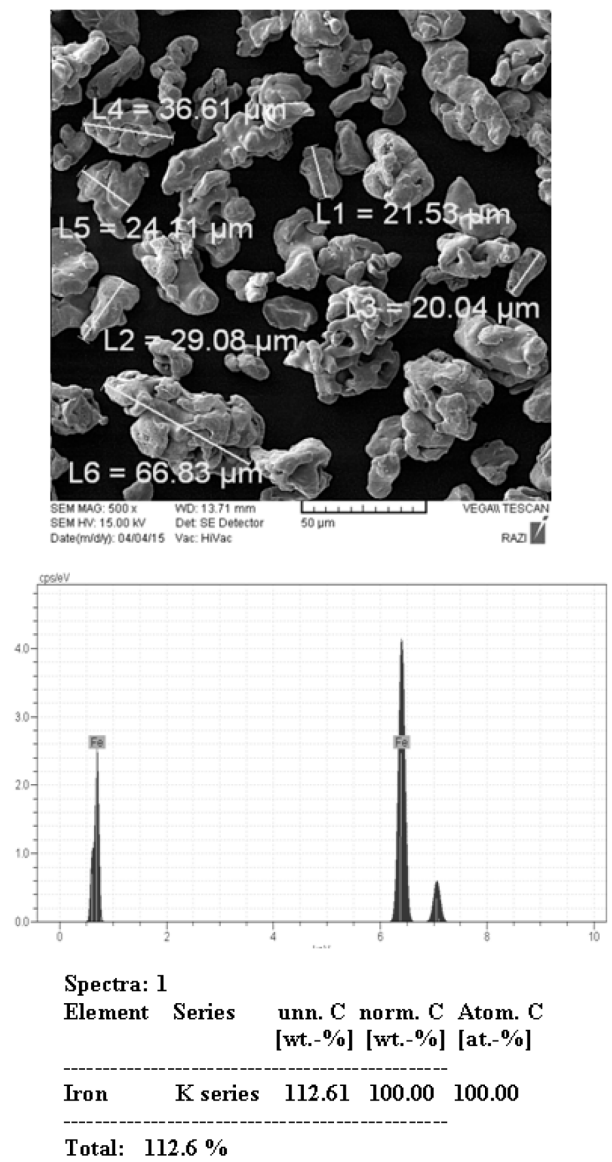

Fig. 2. Image of Iron powder with scanning electron microscopy TESCAN VEGA

According to Figure 3, microstructure of the control specimen includes Ferrite and Perlite in the form of string and layer. Nital solution of $2 \%$ was used for simulation and time of keeping in the Etch solution was 5 seconds.

For studying performance of the structural steel surface groove repairing with the help of flame welding by spraying pure Iron powder, in total, four specimen categories were prepared including one control specimen (without groove) and three grooved specimens with groove width sizes of $0.5,0.75$ and $1 \mathrm{~mm}$ but with the same groove length $(10 \mathrm{~mm})$ and the same groove 
depth $(1 \mathrm{~mm})$. Each category of specimen included four specimens that three specimens were used for tensile test and the other one specimen was used for metallographic test. Repair steps were as follow:

1. The surface was cleaned.

2. Reducing oxyacetylene flame was lit.

3. Groove to be preheated for 5 seconds.

4. Pure Iron powder was sprinkled on the path of reducing oxyacetylene flame to get into the groove.

5. Powder melted in the path of flame.

6. Connection was created after the collision of the molten powder with the wall of groove.

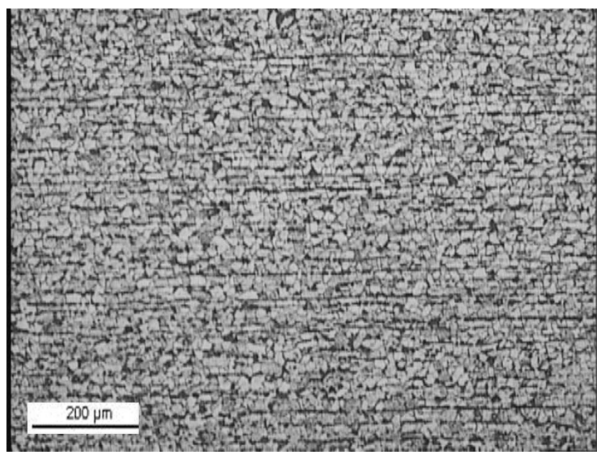

Fig. 3. Microstructure of the base metal, ferrite phase is bright and perlite phase is dark, optical microscopes of Dewinter Company

\section{Results and Discussion}

After repair, tensile properties of the grooved specimens with the groove width sizes of $0.5,0.75$ and $1 \mathrm{~mm}$ were determined and introduced in Table 3, Table 4 and Table 5, respectively. To determine performance of repair method, tensile strength of the repaired specimens was compared with the tensile strength of control specimen in Table 6 and Figure 4.

Table 3 .

Tensile properties of the repaired specimen with the groove width size of $0.5 \mathrm{~mm}$

\begin{tabular}{|c|c|c|c|}
\hline Specimen No. & $\begin{array}{c}\text { Elongation } \\
\text { in percent }\end{array}$ & $\begin{array}{c}\text { Tensile } \\
\text { strength MPa }\end{array}$ & Comments \\
\hline 1 & 23.5 & 468 & \multirow{3}{*}{$\begin{array}{l}\text { Specimen failed } \\
\text { around the repair } \\
\text { area }\end{array}$} \\
\hline 2 & 23.0 & 466 & \\
\hline 3 & 24.0 & 473 & \\
\hline Mean & 23.5 & 469.0 & \\
\hline
\end{tabular}

Table 4.

Tensile properties of the repaired specimen with the groove width size of $0.75 \mathrm{~mm}$

\begin{tabular}{|c|c|c|c|}
\hline Specimen No. & $\begin{array}{l}\text { Elongation } \\
\text { in percent }\end{array}$ & $\begin{array}{c}\text { Tensile } \\
\text { strength MPa }\end{array}$ & Comments \\
\hline 1 & 28.0 & 455 & \multirow{3}{*}{$\begin{array}{l}\text { Specimen failed } \\
\text { around the repair } \\
\text { area }\end{array}$} \\
\hline 2 & 28.5 & 454 & \\
\hline 3 & 27.5 & 450 & \\
\hline Mean & 28.0 & 453.0 & \\
\hline
\end{tabular}

Table 5.

Tensile properties of the repaired specimen with the groove width size of $1 \mathrm{~mm}$

\begin{tabular}{|c|c|c|c|}
\hline Specimen No. & $\begin{array}{l}\text { Elongation } \\
\text { in percent }\end{array}$ & $\begin{array}{c}\text { Tensile } \\
\text { strength } \\
\mathrm{MPa}\end{array}$ & Comments \\
\hline 1 & 32.5 & 454 & \multirow{3}{*}{$\begin{array}{l}\text {-Specimen failed around } \\
\text { the repair area }\end{array}$} \\
\hline 2 & 31.5 & 453 & \\
\hline 3 & 31.5 & 447 & \\
\hline Mean & 31.8 & 451.3 & \\
\hline
\end{tabular}

Table 6.

Comparison of tensile properties of the repaired specimens with control specimen

\begin{tabular}{ccc}
\hline $\begin{array}{c}\text { Groove size } \\
\mathbf{m m}\end{array}$ & $\begin{array}{c}\text { The average tensile } \\
\text { strength MPa }\end{array}$ & $\begin{array}{c}\text { The average } \\
\text { elongation of } \\
\text { relative length \% }\end{array}$ \\
\hline $\mathbf{0 . 5}$ & 469 & 23.5 \\
\hline $\mathbf{0 . 7 5}$ & 453 & 28 \\
\hline $\mathbf{1}$ & 451.3 & 31.8 \\
\hline $\begin{array}{c}\text { Control without } \\
\text { groove }\end{array}$ & 462 & 33.3 \\
\hline
\end{tabular}

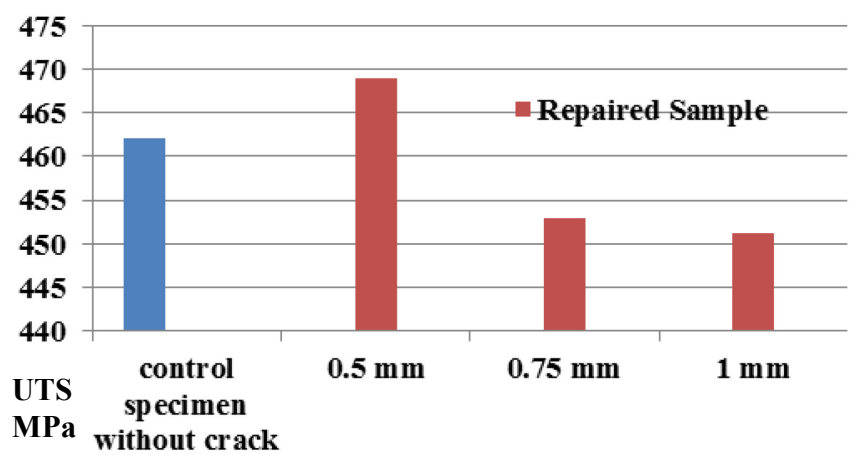

Fig. 4. Comparison of tensile strength of control specimen and repaired specimens

Based on the obtained results from the tensile test, only average tensile strength of the repaired grooved specimen with the groove width size of $0.5 \mathrm{~mm}$ showed $7 \mathrm{MPa}$ more than the average tensile strength of control specimen. While average tensile strength of the repaired grooved specimens with the groove width size of 0.75 and $1 \mathrm{~mm}$ showed relatively $10 \mathrm{MPa}(2.5 \%)$ less than the average tensile strength of control specimen.

Therefore according to Figures 5 to 7 , metallurgical defects in the repaired grooved specimens with the groove width of 0.75 and $1 \mathrm{~mm}$ were more than repaired specimen with the groove width size of $0.5 \mathrm{~mm}$ and so, its effect was appeared in the form of tensile strength reduction.

According to the Manual spraying method in this research, in the Cases where the ceramic tube of pure iron powder spraying, was removed from the flame axle, the unmelted powder was sprayed into cracks. Therefore, the black areas in the images $(5,6$ and 7$)$ can be seen is pure iron powder. 


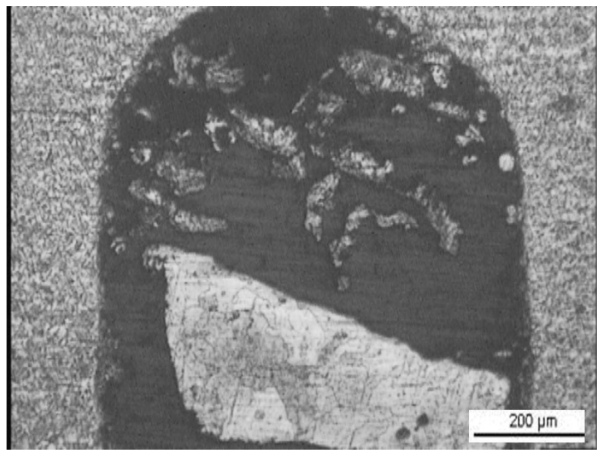

Fig. 5. Repaired specimen with the groove width size of $0.5 \mathrm{~mm}$, metallurgical defects in the dark color in the repaired place, optical microscope of Dewinter Company

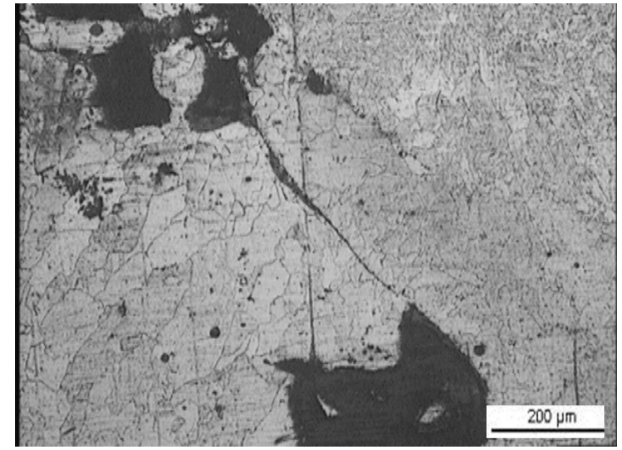

Fig. 6. Repaired specimen with the groove width size of $0.75 \mathrm{~mm}$, metallurgical defects in the dark color in the repaired place, optical microscope of Dewinter Company

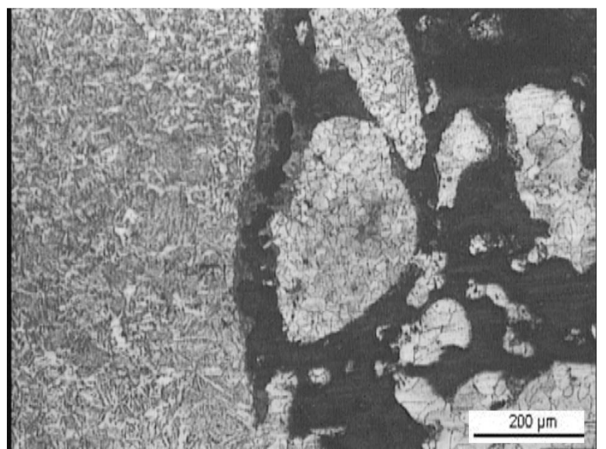

Fig 7. Repaired specimen with the groove width size of $1 \mathrm{~mm}$, metallurgical defects in the dark color in the repaired place, optical microscope of Dewinter Company

\section{HAZ (Heat Affected Zone)}

In this method the mass of the filler material $(\mathrm{m})$ is very low, so according to the $\mathrm{Eq} 1$, The heat input $(\mathrm{Q})$ is very low and as a result the HAZ is too short. It is an advantage of this method.

$Q=m \cdot C \cdot \Delta T$

The macroscopic image of penetration illustrated in Figure 8.

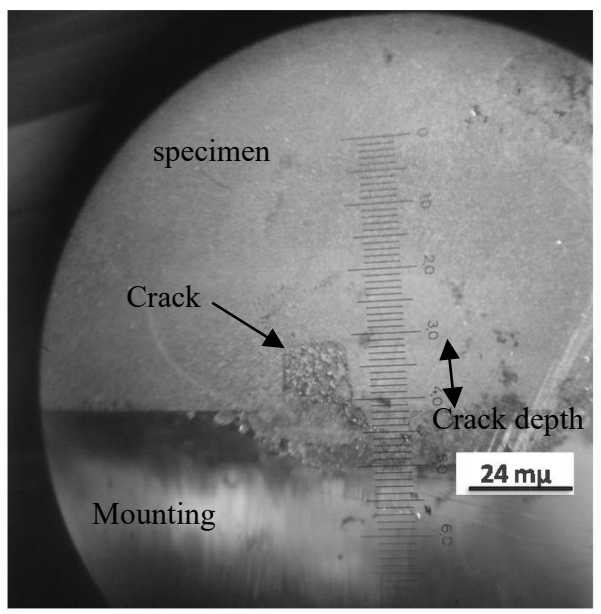

Fig. 8. The macroscopic image to check the influence of pure iron into the repaired steel specimens with groove width size of $1 \mathrm{~mm}$, by microscope of Dewinter Company

\section{Conclusions}

In this research, it was tried to repair structural steel surface grooves with the help of flame welding by spraying pure iron powder in the reducing flame path of oxyacetylene. So, four specimen categories were prepared including one control specimen and three other specimens as grooved specimens with $12.5 \mathrm{~mm}$ length, $1 \mathrm{~mm}$ depth and $0.5,0.75$ and $1 \mathrm{~mm}$ groove width sizes. According to the obtained results from tensile test, this method was useful for surface grooves of structural steel with the groove sizes from 0.5 to $1 \mathrm{~mm}$, because repair could maintain tensile strength of grooved specimens with the sizes from 0.5 to $1 \mathrm{~mm}$ in comparison with tensile strength of control specimen with the margin of $2.5 \%$.

\section{References}

[1] Mirhedayatian, S.M., Vahdat, S.E., Jelodar, M.J., \& Saen, R.F. (2013). Welding process selection for repairing nodular cast iron engine block by integrated fuzzy data envelopment analysis and TOPSIS approaches. Materials \& Design. 43, 272-82.

[2] Huan, S. (1995). Flame spray welding using tungsten carbide alloy powder: S. Huan et al. (Shenyang Polytechnic University, Shenyang, China). Metal Powder Report. 1996. 51:44. PM Technol. 13(4), 259-264. (In Chinese.).

[3] Miki, C., Hanji, T. \& Tokunaga, K. (2012). Weld Repair for Fatigue-Cracked Joints in Steel Bridges by Applying Low Temperature Transformation Welding Wire. Weld World. 56. 40-50.

[4] Sterjovski, Z. (2010). Pad-Weld Repairs of in-Service HighStrength Steel Plate used in Seawater Environments. Weld World. 54. R173-R81.

[5] Committee, A.I.H., Olson, D.L. (1993). ASM handbook: Welding, brazing, and soldering: ASM International. 
[6] Nakamura, H., Jiang, W., Suzuki, H., Maeda, K-i. \& Irube, T. (2009). Experimental study on repair of fatigue cracks at welded web gusset joint using CFRP strips. Thin-Walled Structures. 47, 1059-68.

[7] Zhao, X., Wang, D. \& Deng, C. (2014). Research on fatigue behavior of welded joint spraying fused by low transformation temperature alloy powder. Materials \& Design. 53, 490-6.
[8] Zhao, X., Wang, D. \& Deng, C. (2011). Fatigue behavior of welded joint spray fused by nickel-base alloy powder. Journal of Materials Processing Technology. 211, 2039-44.

[9] ASTM A370, (2014). Standard Test Methods and Definitions for Mechanical Testing of Steel Products, ASTM International, West Conshohocken, PA, www.astm.org 